\title{
NMES
}

New Middle Eastern Studies

ISSN: 2051-0861

Publication details, including guidelines for submissions:

https://journals.le.ac.uk/ojs1/index.php/nmes

\section{Turkey as a Mediator in the Middle East: A Neoclassical Realist Analysis}

Author(s): Yusuf Bera Topaloğlu

To cite this article: Topaloğlu, Yusuf Bera (2021) "Turkey as a Mediator in the Middle East: A Neoclassical Realist Analysis", New Middle Eastern Studies 11 (2), pp. 43-72.

Online Publication Date: 2 March 2022

\section{Disclaimer and Copyright}

The NMES editors make every effort to ensure the accuracy of all the information contained in the journal. However, the Editors and the University of Leicester make no representations or warranties whatsoever as to the accuracy, completeness or suitability for any purpose of the content and disclaim all such representations and warranties whether express or implied to the maximum extent permitted by law. Any views expressed in this publication are the views of the authors and not the views of the Editors or the University of Leicester.

Copyright New Middle Eastern Studies, 2022. All rights reserved. No part of this publication may be reproduced, stored, transmitted or disseminated, in any form, or by any means, without prior written permission from New Middle Eastern Studies, to whom all requests to reproduce copyright material should be directed, in writing.

\section{Terms and Conditions}

This article may be used for research, teaching and private study purposes. Any substantial or systematic reproduction, re-distribution, re-selling, loan or sub-licensing, systematic supply or distribution in any form to anyone is expressly forbidden.

The publisher does not give any warranty express or implied or make any representation that the contents will be complete or accurate or up to date. The accuracy of any instructions, formulae and drug doses should be independently verified with primary sources. The publisher shall not be liable for any loss, actions, claims, proceedings, demand or costs or damages whatsoever or howsoever caused arising directly or indirectly in connection with or arising out of the use of this material. 


\title{
Turkey as a Mediator in the Middle East: A Neoclassical Realist Analysis
}

\author{
Yusuf Bera Topaloğlu*
}

\begin{abstract}
This article aims to analyse the factors leading to varying trends in Turkey's activeness as a mediator in the Middle East during the post-Cold War period. It seeks to investigate which variables - from various levels of analysis - have influenced Turkey's activeness in mediation initiatives in the Middle East during this period. Moreover, it also aims to explore the relationships between these variables in the scope of which variables come into play in which conditions and, more importantly, which one of them assumes the primary role within this set of interactions. Utilising the theoretical framework of neoclassical realism and international mediation literature, this study specifies an independent variable (security concerns about the neighbouring part of the region), three intervening variables (eagerness of foreign policymakers for diplomatic expansion, domestic institutional constraint, and diplomatic and economic capacity) and finally, a dependent variable (activeness of Turkey as a mediator in the Middle East) to address these questions systematically. By analysing this process through these variables, this article reaches the following two main conclusions: (1) when security concerns increase, activeness decreases. (2) When security concerns decline, the levels of intervening variables determine the degree of activeness.
\end{abstract}

Keywords: Turkey; Middle East; Mediation; Neoclassical Realism; Foreign Policy Analysis

\section{Introduction}

Mediation, as a foreign policy tool, has occupied a significant position in Turkish foreign policy in the post-Cold War period. In addition to Turkey's attempts to institutionalise mediation within the bodies of international organisations, it has also undertaken peace broker roles within various conflicts in different regions such as the Middle East, the Balkans, Africa, the Caucasus, Central Asia and even the Far East Asia. The Middle East, unsurprisingly, is the region where Turkey's mediation efforts have mainly been concentrated. However, examining the conflicts in which Turkey assumed a mediator role in this period reveals variations in its activeness. While the level of Turkey's activeness as a mediator increased in some periods, it declined in others. For instance, while Turkey needed the intervention of Egypt as a mediator to come to an agreement with Syria to resolve the then intensifying security-oriented problems in 1998, a decade later, it became the primary facilitator in the conflicts Syria had with Israel, Iraq and Saudi Arabia in 2008 and 2009.

\footnotetext{
"Yusuf Bera Topaloğlu, PhD Candidate, School of Social and Political Science, University of Edinburgh, Edinburgh, UK. Email: yusuf.topaloglu@ed.ac.uk
} 
Today, again after about a decade, the increasingly deteriorating ties between Turkey and Syria have become the subject of mediation for other countries in the region.

This article seeks to analyse the factors that influenced Turkey's activeness as a mediator in the Middle East in the post-Cold War period, in particular between 1994 and 2016. It aims to address the question of why the level of Turkey's activeness as a mediator in the Middle East varied from period to period during the post-Cold War era. In this regard, this article will investigate which factors from which levels of analysis were influential in terms of varying levels of Turkey's activeness and which factor played the primary role during this process.

Along with the aforementioned increase in Turkish mediation efforts in the last two decades, the number of studies on Turkey's policy as a mediator has increased considerably. Particularly in the last decade, various books, articles, and dissertations were written on this topic. Several case/field studies were conducted in the regions or countries where Turkey attempted to play a mediator role, showing a significant rise compared to the lack of literature in the previous years.

In a similar vein to this article, one element of this literature explores the factors behind the rising trend of mediation within Turkish foreign policy. Beriker (2016) establishes a close link between the foreign policy tendencies of Turkey as a middle power and the United States as a great power between 2002-2015. Beriker argues that once the United States adopted a revisionist strategy during the first decade of the century, thanks to the unipolarity in world politics, Turkey - in parallel - undertook a mediator role as a complementary foreign policy for the goals of the United States. However, when the United States began to embrace the strategy of 'balanced internationalism' due to the transformation of the unipolar world system, Turkey started to act more independently to promote its position as a regional power. This assertive foreign policy, Beriker contends, eventually damaged the active and effective mediator image of Turkey in the 2010s. In an article written in the early years of the AKP (Justice and Development Party) government, which made a significant contribution to the development of this study's theoretical framework, Oğuzlu (2007) focuses on the effects of national security and credibility/legitimacy on Turkey's soft power identity in a broader sense rather than its mediation capabilities. Oğuzlu argues that the extent to which Turkey can embrace this identity would be based on how it can manage the relationship between these two concepts.

From a different perspective, Kürüm (2011) and Avan (2019) discuss the place of the 'Europeanisation of Turkey' and the EU with its norms and principles and whether it has been a determinant in Turkey's activeness as a peace broker in the last two decades. Kürüm empirically asserts that although the improving ties and membership negotiations with the EU played a supportive role in Turkey's mediation attempts, they have not played a determinant role in this process. There is no conditionality between Turkey's increasing mediation efforts and the positive developments within Turkey's membership process. Instead, domestic drivers, such as the ruling elite's ideological approach, have mattered more in Turkey's foreign policy trajectory as a mediator. Similarly, Avan notes that the norms and values of the EU are compatible with how Turkey seeks to initiate mediation between countries. These principles have strengthened Turkey's hand in its mediation efforts. However, this does not necessarily mean that these attempts were the result of the Europeanisation of Turkey. 
Rather, the central driving forces were the rational reasons related to the political agenda of Turkey and strongly shaped by its national interests.

In other respects, some works look at the place of perceptions about the traditional Western mediators in the region as underlying factors in the rise of Turkey and other untraditional regional mediators in the Middle East in the last two decades. For instance, Akpinar (2015) argues that the mistrust against the traditional Western mediators in the region, as well as their relatively non-interventionist attitudes towards the Middle East during the Arab Spring, has provided a suitable environment for countries such as Iran, Qatar and also Turkey to embrace vibrant foreign policies on regional issues. More specifically, while discussing Turkey's mediation in Iran, Bonab (2009) adopts a similar position to Akpinar, arguing that Iran's doubt and distrust of conventional Western mediators enabled Turkey to undertake a facilitator role in this dispute.

Some studies focus on explaining the changing activeness of Turkey as a mediator in the Middle East by discussing the mediation styles assumed by Turkey during the crises. Çuhadar (2007) discusses Turkey's mediation style in the Israeli-Palestinian conflict and suggests that Turkey should act as a facilitation-type mediator, adopting all means of impartiality and embracing the role of channel provider between the two sides of the conflict, rather than following a power politics strategy that requires more resources, leverage and power than Turkey could afford. In another article that Çuhadar co-wrote with Altunışık three years later, they review Turkey's mediation role in the Arab-Israeli conflicts. They suggest that although Turkey had adopted a neutral facilitator role at the beginning of its mediation efforts, Turkey's position altered following Israel's deadly military operations in Gaza in 2008. Its close ties with Hamas pictured Turkey as it attempts to embrace a principal power role during the negotiations. That, eventually, risked and threatened Turkey's impartiality and the future of the peace negotiations (Altunışık and Çuhadar 2010).

Similarly, Köse (2013) discusses the relationship between Turkey's mediation style and its activeness as a mediator in the Middle East. Köse argues that Turkey's transformative conflict resolution efforts face difficulties in the region because of instability and turmoil stemming from the Arab Spring. He points out that less ambitious conflict management provided greater success for Turkey in the past compared to the more ambitious attitude Turkey has followed since the beginning of the uprisings in the region, particularly in Syria. From a critical point of view, Mitchell (2015) finds Turkey's willingness to assume a vigorous policy for conflict management in the crises taking place in its region as a difficult objective for Turkey. Mitchell asserts that Turkey does not have enough capacity in terms of 'carrots' and 'sticks' to assume a mediator role in the ongoing conflicts in the Middle East. Also, the Arab uprisings, Mitchell argues, have damaged Turkey's unbiased third-party image as the developments in Turkey's neighbourhood have a direct critical impact on the country.

Finally, some studies emphasise the role of individual political figures and their foreign policy doctrines. Aras (2014) points out how Turkey rose as an important soft power by employing the instruments of peace-building and mediation during the Davutoğlu Era. Öget (2019) discusses the influence of Ahmet Davutoğlu on Turkey's effectiveness as a mediator in the Middle East by referring to several of Davutoğlu's central foreign policy doctrines such 
as 'zero problems with neighbours', also mentioning concepts attributed to the foreign policy vision of Davutoğlu, such as 'Neo-Ottomanism'.

In light of the above discussions on the driving forces behind Turkey's activeness as a mediator, one part of the literature attempts to explore these motives by attaching essential importance to regional and international developments, correlating the extent of Turkey's peace broker activity with structural changes in the grand strategy of the United States or with the alterations within the structure of Turkey-EU relations. On the other hand, some studies focus on the role of the AKP and its ideology-based approach encompassing NeoOttomanism and, according to some, even Islamism, as the milestone for Turkey's increasing and decreasing activeness as a mediator, particularly in the Middle East. A considerable number of studies underscore the central significance of the key role played by foreign policy figures such as Ahmet Davutoğlu in this process.

This article, however, will analyse the underlying factors of the varying trajectories in Turkey's activeness as a mediator in the Middle East during the entire post-Cold War period. Thus, this study seeks to cover not only the AKP period but also the decade before the AKP's rule to view the factors that created these alterations comparatively. It aims to explore this process differently from the perspectives in the literature, evaluating various levels of analysis by incorporating structural and domestic level variables to enhance the explanatory power of the study. By doing so, this article seeks to contribute to the literature, especially in the context of following two points that are currently lacking: (1) analysing Turkey's mediation initiatives in the Middle East, not only concentrating on the AKP period - often called the Davutoğlu era - but also comparatively examining the entire period in the postCold War era; (2) incorporating different dimensions into the analysis by establishing relationships between them.

\section{Theoretical Framework}

\section{a) Mediation}

The literature contains various definitions for mediation; some focus on specific characteristics of mediation to form a definition. Others concentrate on clarifying the distinctive features of mediation, distinguishing it from other conflict management or resolution means such as arbitration and peacekeeping. One of the central disputes in the literature is whether being impartial and unbiased is a prerequisite for a mediator or whether making a distinction between being neutral and being impartial is relevant or necessary. Considering all of these debated points, the principal features of mediation specified in Bercovitch's definition provide a more inclusive and comprehensive interpretation. Bercovitch (2009: 343) defines mediation as:

...a process of conflict management, related to but distinct from the parties' own negotiations, where those in conflict seek the assistance of, or accept an offer of help from, an outsider (whether an individual, an organisation, a group, or a state) to change their perceptions or behaviour, and to do so without resorting to physical force or invoking the authority of law. 
Since this study aims to analyse the driving forces behind Turkey's activeness as a mediator in the Middle East, incorporating insights from the literature of international mediation regarding the factors that impact a country's activeness as a mediator into the analysis would contribute much to its theoretical framework. In this sense, Touval and Zartman (1985: 37) specify their stance by stating that the concern of conflicting parties is not "whether the mediator is impartial, but whether it can provide an acceptable outcome'. Bercovitch and Jackson (2009: 36) similarly emphasise leverage and resources, such as economic, diplomatic skills and status, that a mediator can utilise during the mediation process rather than concentrating on impartiality as the essential elements of effective mediation. Thus, Turkey's diplomatic and economic capacity will be included in the analysis as a variable while analysing its activeness as a mediator in the Middle East.

\section{b) Neoclassical Realism}

Even though international relations theories literature had been dominated by structure-based approaches within both realist and liberal paradigms until the end of the 1990s, this scholarship has witnessed a 'domestic politics turn' in the last 25 years (Kaarbo 2015). In respect of the debates about focusing on domestic variables more in international relations discipline, Moravcsik (1997) initially contributed to the liberal paradigm with his preferencebased approach. Then, Rose (1998) highlighted the emergence of a new approach within the realist paradigm, reviewing the works of five scholars (Brown, Christensen, Schweller, Wohlforth and Zakaria) who position themselves in the realist school but do incorporate domestic variables into their analyses while still prioritising international or structural variables. Rose termed this novel approach within the realist international relations theory as 'neoclassical realism'. Rose calls it realist because these scholars acknowledge that a country's primary driver in the foreign policymaking process is its position in international politics in the sense of its relative material capacity. He names it neoclassical because they (these scholars) also posit that domestic intervening variables come into play in terms of filtering signals of the international system that are generally complex and indirect in the foreign policymaking process (1998: 146).

In this respect, while analysing states' foreign policy behaviours, neoclassical realism accepts the international system or structural stimuli as the independent variable and unitlevel variables as intervening variables. Thus, it is central in this theory to focus on how systemic pressures are filtered by domestic factors while investigating states' foreign policy behaviours. The incorporated domestic intervening variables vary according to the topics on which scholars focus. For instance, Rose (1998: 152) mentions two domestic variables (domestic state structure and decision-makers' perceptions), whereas Schweller (2004: 169) develops a more exhaustive framework in his analysis of unit-level variables and posits four intervening variables (elite consensus, elite cohesion, social cohesion and government or regime vulnerability).

Contributing to the literature with the most ambitious and comprehensive study on

neoclassical realism, Ripsman, Taliaferro and Lobell (2016) present this approach as both the theory of foreign policy and also the theory of international politics. Firstly, they summarise 
the literature on neoclassical realism into two distinct types. Type I is composed of scholars whose works were analysed by Rose's review essay in 1998. This type of neoclassical realism merely intends to explain the anomalies that structural realism does not address and undertakes the role of providing explanations for states' foreign policy choices instead of international politics (Ripsman et al., 2016: 26-29). The Type II approach, including the edited book of the authors of this study (Ripsman et al., 2009), on the other hand, goes beyond just explaining the anomalies of structural realism and seeks to form a theory of foreign policy analysis by presenting a more suitable basis to analyse both foreign policy behaviours and also international alterations (Ripsman et al., 2016: 29-31). Finally, they call their contribution to the literature with this book Type III neoclassical realism that does not only intend to provide a foreign policy analysis theory but also seeks to explicate international politics with a theoretical perspective (Ripsman et al., 2016: 12).

They position neoclassical realism in the broad tradition of 'Realpolitik' instead of defining it as an extension of neorealism (Ripsman et al., 2016: 8). In addressing the shortcomings of neorealism, Type III neoclassical realism incorporates several domestic intervening variables, shown in Figure 1. Formulating these variables, the scholars specify that the question of which intervening variable influences the dependent variable more can vary according to 'different degrees over time' (Ripsman et al., 2016: 61) to address the critics of neoclassical realism generally arguing that domestic variables are utilised in an ad hoc manner and a lack of clarity exists regarding which variable matters more and which matters less (see Legro and Moravcsik, 1999). Lastly, as stated above, Type III neoclassical realism considers international outcomes as the dependent variable in addition to the foreign policy behaviours of states. It postulates that grand strategic policies or choices of great powers in their foreign policies cumulatively affect and shape international outcomes and politics in the long run and analyses the international structure in terms of the nature of the strategic environment (permissive or restrictive), the polarity (unipolar, bipolar or multipolar) and the clarity (high or low) in international politics (Ripsman et al., 2016: 54-55 and 82).

Figure 1 illustrates the independent (structural stimuli), intervening (leader images, strategic culture, state-society relations and domestic institutions) and dependent variables (policy responses and international outcomes) that Type III NCR focuses on and the proposed relationship between these variables:

Figure 1. Type III Neoclassical Realist Model (Ripsman et al., 2016: 34)

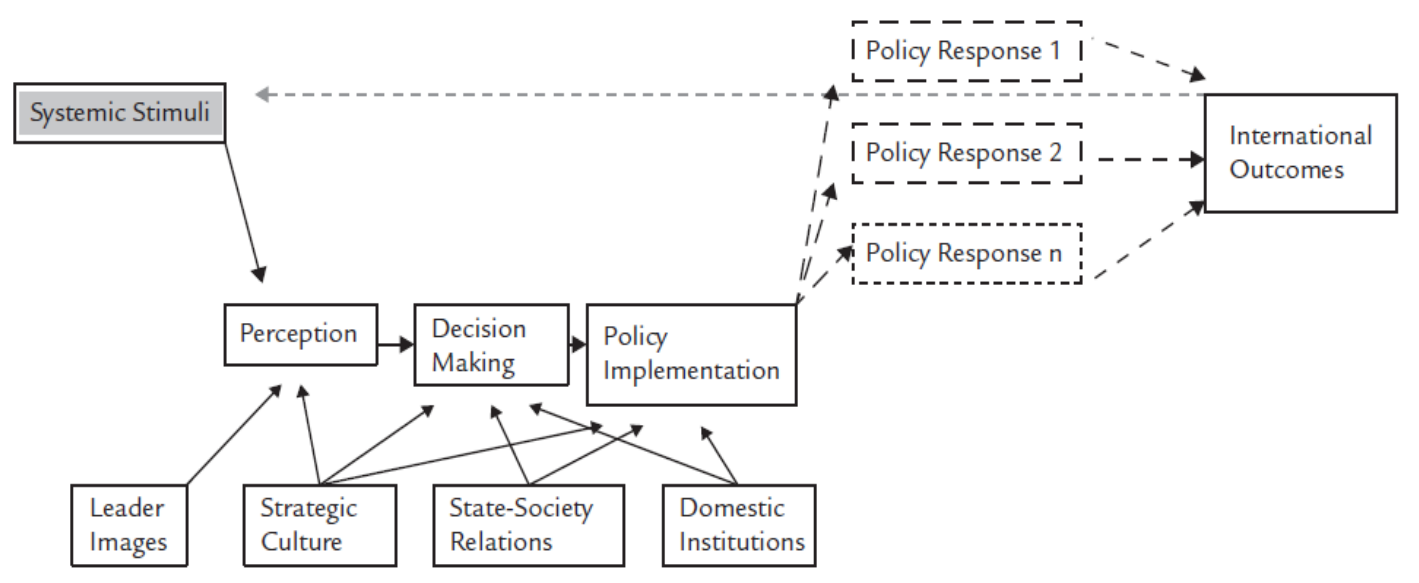




\section{c) Theoretical Model and Methodology}

Borrowing from the theoretical framework of neoclassical realism and the literature of international mediation, this article's theoretical model specifies one independent variable, three intervening variables and one dependent variable to analyse Turkey's facilitation efforts in the Middle East after the Cold War. The independent variable is the security concerns of Turkey in its relations with countries in the region, especially its neighbours. The intervening variables are foreign policymakers' perceptions, domestic institutional constraint and capacity. The dependent variable is Turkey's activeness as a mediator in the Middle East. The analysis of these variables will be made by dividing the process into five time periods: 19941998, 1999-2002, 2003-2007, 2008-2011 and 2012-2016. The degrees of the variables will be given five values: very low, low, medium, high and very high. Table 1 illustrates the theoretical model and periodisation of this study.

Table 1. Theoretical Model and Periodisation

\begin{tabular}{|c|c|c|c|c|c|}
\hline \multirow[b]{2}{*}{ Periods } & Independent & \multicolumn{3}{|c|}{ Intervening Variables } & \multirow{2}{*}{\begin{tabular}{|c|}
$\begin{array}{c}\text { Dependent } \\
\text { Variable }\end{array}$ \\
\\
Activeness \\
as a \\
Mediator
\end{tabular}} \\
\hline & $\begin{array}{l}\text { Security } \\
\text { Concerns }\end{array}$ & $\begin{array}{c}\text { Foreign } \\
\text { Policymakers' } \\
\text { Perceptions } \\
\text { (eagerness for } \\
\text { diplomatic } \\
\text { expansion) }\end{array}$ & $\begin{array}{c}\text { Domestic } \\
\text { Institutional } \\
\text { Constraint } \\
\text { (Pressure of } \\
\text { Military or } \\
\text { Coalition } \\
\text { Parties) }\end{array}$ & $\begin{array}{c}\text { Capability/Capacity } \\
\text { (Diplomatic and } \\
\text { Economic) }\end{array}$ & \\
\hline $\begin{array}{c}1994 \\
1998\end{array}$ & & & & & \\
\hline $\begin{array}{c}1999- \\
2002\end{array}$ & & & & & \\
\hline $\begin{array}{c}2003- \\
2007\end{array}$ & & & & & \\
\hline $\begin{array}{c}2008- \\
2011\end{array}$ & & & & & \\
\hline $\begin{array}{c}2012- \\
2016\end{array}$ & & & & & \\
\hline
\end{tabular}

While categorising the periods, structural changes and developments that have profound reflections on Turkey's security concerns are considered as the main determinant. In addition, some domestic changes accepted as significant developments in terms of the transformation 
of Turkey and its foreign policy behaviours, such as the victory of the AKP in the 2002 elections, are also taken into consideration during the categorisation process. The beginning year is taken as 1994 because that is when the first mediation attempt of Turkey after the Cold War took place. The analysis of this article covers the period until 2016 because several domestic, regional and international tectonic changes occurred, affecting Turkey's foreign policy preferences, particularly towards the Middle East, in that year. These include the July 15 coup attempt, the beginning of Turkey's large-scaled cross-border operation to Northern Syria in August, the election of Donald Trump in the United States, the decision by Iran, Turkey and Russia to start the Astana Process for seeking a solution in Syria and the resignation of Ahmet Davutoğlu as the prime minister. Lastly, this study is aware of the cumulative relationship between the successive periods. Therefore, when analysing one period, reference will also be made to the impacts of the previous periods.

Regarding the independent variable, this study seeks to analyse the period after the Cold War, considering the structural ramifications of the end of the Cold War for international politics and the significant repercussions of this change for Turkey's foreign policy preferences. As the strict constraints of polarisation in international politics had restricted Turkey, whose geo-strategic position had worsened its situation in terms of following a flexible policy in the region, the end of the Cold War provided Turkey with more manoeuvring capability in its relations with countries in the region. Thus, this study has chosen to analyse the period after the end of the Cold War and has not incorporated this tectonic development in the international system into the analysis as a separate variable.

The security concerns of Turkey, which have been strongly influenced by the international and regional structural changes and developments, are taken as the independent variable as it is argued in this article that these concerns of Turkey in its relations with countries in the Middle East played a primary role in Turkey's activeness as a mediator in the region. In other words, the effects of international and regional events such as the September 11 attacks or the Arab Spring will be analysed within the context of how they influenced the level of security concerns of Turkey in its relations with countries in the region, particularly the neighbouring countries: Syria, Iraq and Iran. In the light of these, the assessment of the level of Turkey's security concerns will be made by analysing some relevant questions such as how the neighbouring countries position themselves against the PKK or its affiliations, how many cross-border military operations are carried out by Turkey, whether or to what extent the neighbouring countries embrace expansionist policy in the region (for instance, as seen by Iran after 2011) and eventually to what extent and in what senses the domestic disturbances (for example, civil wars, as seen in Iraq and Syria after the uprisings) of the countries in the region, particularly neighbouring countries, cause a vacuum of power that revisionist terrorist organisations can fill by posing a substantial security threat to Turkey.

Utilising the approach of neoclassical realism, foreign policymakers' perceptions and domestic institutional constraints are taken as intervening variables. For this study, the effect of foreign policymakers' perceptions will be examined by considering their eagerness for diplomatic expansion. Books, articles, interviews and speeches of key foreign policymakers will be analysed to measure their eagerness for diplomatic expansion. As to domestic institutional constraint, while the effect of civil-military relations on foreign policymaking and particularly on diplomatic expansion will be at the centre of the discussion, the influence 
of coalition governments will also be considered. In order to measure the level of domestic institutional constraint, indicators such as whether the military intervened in politics through, for instance, political memorandums and whether high-level military personnel undertook a foreign policymaker role via their leverage on politicians or directly carrying out negotiations with other countries by circumventing politicians will be investigated.

The third intervening variable, capability or capacity, is incorporated into this study, borrowing from international mediation literature. As mentioned in the part of international mediation referring to the remarks of Bercovitch, Touval and Zartman, the economic and diplomatic capability of a country significantly influences its mediator role. The conflicting parties should believe in the capability of the third party to provide an agreeable outcome. Turkey's economic capability will be measured by analysing its economic growth and, more importantly, the changes in the trade volume between Turkey and the Middle East. As a measure of Turkey's diplomatic capability, the transformation of Turkey's image in the eyes of not only the Middle Eastern countries but also the EU countries, the United States and, in some cases, the UN will be taken into consideration through, for example, examining some events such as Turkey's membership negotiations with the EU, the election of Turkey to nonpermanent membership of the United Nations Security Council, survey studies such as the TESEV (Turkish Economic and Social Studies Foundation) reports on the perception of Turkey in the Middle East, and interviews and works on the rise and fall of the Turkish model, especially during the Arab uprisings.

Lastly, measurement of the dependent variable, Turkey's activeness as a mediator in the Middle East, will be conducted by examining the number of mediation initiatives carried out by Turkey in the specified periods. Table 2 shows Turkey's mediation attempts since the end of the Cold War. The evaluation of the level of the dependent variable will be made by referring to this table.

Table 2. Turkey's Mediation Attempts between 1991-2020

Conflict/Case

Bosnian-Croatian Forces

Goverment of Moldova-Gagauzs

The Neighbouring Countries of Iraq

Azerbaijan-Georgia

January $\mathbf{2 0 0 0}$

Israel Palestine

Initiative of Neighbouring Countries of Iraq
April 2002

\section{Month/Year}

March 1994

May 1994

1998

$2003-2008$ 


\begin{tabular}{|c|c|}
\hline Pakistan-Israel & September $\mathbf{2 0 0 5}$ \\
\hline Shiite-Sunni Parties in Iraq & December 2005 \\
\hline Lebanon-Israel & 2006 \\
\hline Israel-Palestine & November $\mathbf{2 0 0 7}$ \\
\hline Pakistan-Afghanistan & $2007-2014$ \\
\hline Israel-Palestine & 2008 \\
\hline Israel-Syria & 2008 \\
\hline Parties in Lebanon & May 2008 \\
\hline Caucasus Stability and Cooperation Platform & $2008-2009$ \\
\hline Iran-P5+1 Countries & $2009-2010$ \\
\hline Philippine Government-the MILF & $2009-2012$ \\
\hline Serbia-Bosnia & October $\mathbf{2 0 0 9}$ \\
\hline Syria-Iraq & September $\mathbf{2 0 0 9}$ \\
\hline Syria-Saudi Arabia & 2009 \\
\hline Croatia-Bosnia & January 2010 \\
\hline Uzbek-Kyrgyz Conflict in Kyrgyzstan & 2010 \\
\hline Sunni-Shiite parties of Iraq & 2010 \\
\hline Parties in Lebanon & January 2011 \\
\hline Government of Bahrain-Opposition Groups & 2011 \\
\hline Qaddafi Government-Transitional National Council & 2011 \\
\hline Sunni leaders in Iraq & 2011 \\
\hline Sunni-Shiite Turkmen Groups in Iraq & 2011 \\
\hline Somalia-Somaliland & 2013 \\
\hline Pakistan-Afghanistan & $2007-2014$ \\
\hline Philippine Government-the MILF & $2009-2012$ \\
\hline
\end{tabular}




\begin{tabular}{|lc|}
\hline Mediations in Hostage Crises & $\mathbf{2 0 0 6}-\mathbf{2 0 1 1}$ \\
\hline Israeli Soldier Kidnapped by Hamas & April $\mathbf{2 0 0 7}$ \\
French Citizen Detained in Iran & $\mathbf{2 0 1 0}$ \\
4 New York Times Journalists Detained in Libya & March $\mathbf{2 0 1 1}$ \\
Guardian Journalist Detained in Libya & March $\mathbf{2 0 1 1}$ \\
\hline Mediations in the IGOs/Other & July $\mathbf{2 0 0 5}$ \\
\hline Alliance of Civilisations in the UN & September $\mathbf{2 0 1 0}$ \\
Group of Friends of Mediation in the UN & $\mathbf{2 0 1 0}-\mathbf{2 0 1 9}$ \\
Group of Friends of Mediation in the UN & $\mathbf{2 0 1 4}-\mathbf{2 0 1 9}$ \\
Friends of Mediation Group in the OSCE & $\mathbf{2 0 1 8}-\mathbf{2 0 1 9}$ \\
Contact Group of Friends of Mediation in the OIC & $\mathbf{2 0 1 2}-\mathbf{2 0 1 9}$ \\
Istanbul Mediation Conference & \\
\hline
\end{tabular}

\section{Turkey: As a Mediator in the Middle East}

a) The Effect of Two and a Half Wars Strategy? Security-Oriented Foreign Policy (19941998)

Even though Turkey sought to pursue diplomatic expansion thanks to the end of the Cold War and its restrictive effect on Turkish foreign policy, the turmoil in the neighbouring regions and the increasing power of the PKK utilising the power gap in Northern Iraq following the Gulf War did not provide a suitable environment for Turkey to attain its diplomatic goals. In the Middle East, Syrian aid for the PKK, the unprecedented alliance between Syria and Greece, and strained relations with Iran regarding 'religious fundamentalism' led Turkey to securitise its foreign policy.

As an illustrative indicator of this security-oriented aspect towards the Middle East in this term, the notion of the "two and a half war strategy" developed by the retired Ambassador Şükrü Elekdağ in 1994 can be discussed here. Proposing this idea for the agenda, Elekdağ (1994) suggested that Turkey should develop strategies and make provisions for the threats coming from inside (PKK) and outside (Syria and Greece) of Turkey. Turkey's main security concern was that the PKK had been increasing its power in Northern Iraq since the beginning of the decade by establishing bases. Three cross-border operations were 
launched to the area to deal with this problem. Besides, the close ties between Syria and Greece, which had transformed into a military alliance in terms of a common defence agreement in 1995, and Syria's permission for the PKK leader to reside there led to a deep deterioration of relations between Turkey and Syria in that period. Another problem between the two countries was the water crisis stemming from the Great Anatolian Project through which Turkey was planning to use the Euphrates to enhance its irrigation and energy capacity. Syria and Iraq, as the other party of the conflict, criticised and protested this project by mobilising other Arab countries against Turkey (Sayari 1997: 48-49).

Turkey's ties with Iran also underwent deterioration, essentially relating to Turkey's internal security concerns. The National Security Policy Document of 1995 specified 'religious fundamentalism' and 'irredentism' as the two security threats to Turkey, obviously referring to Syria and Iran (Altunışık 2011: 571). The rise of political Islamism and its substantial reflections in Turkish politics, as seen clearly in the success of the Islamist Welfare Party in the local and general elections in 1994 and 1995, were linked to Iran by the military that enjoyed significant influence over domestic and foreign policymaking in this period. Given all these security-oriented relations with its neighbours, Turkey attempted to balance these threats against its national security by establishing strong ties, which were even defined by some as an 'axis' (Pipes 1997) or 'alliance' (Waxman 1999: 26), with Israel that had similar security concerns against Syria and Iran. Several defence agreements were signed between the countries in 1996 (Altunışık 2000: 186-187).

In domestic politics, Turkey was suffering from instability because of short-term coalitions. This period witnessed five coalition governments and eight foreign ministers. Furthermore, as some foreign ministers like Murat Karayalçın, Erdal İnönü, Deniz Baykal and Tansu Çiller were also leaders of their political parties; their main political agendas were firmly occupied by domestic politics rather than foreign policy. Even when Erbakan who sought to follow a vigorous policy, particularly in relations with Muslim countries by paying official visits came to power, these efforts did not change Turkey's security-oriented perspective toward the Middle East and the most significant defence agreements with Israel were concluded in this period (Frrat and Kürkçüoğlu 2001: 560-563).

The 1990s witnessed to the 'golden age' of military intervention in politics in Turkey (Uzgel 2003: 178). The military and its security-first perspective played an essential role in Turkey's relations with the Middle East, while civilian politics suffered from weak and shortterm coalitions. Since the military labelled the Welfare Party as the centre of fundamentalist Islamism and worried about an Islamist turn in foreign policy under Prime Minister Erbakan, it took the initiative in improving ties with Israel and several reciprocal visits were paid by top-level military personnel of both countries alongside military and economic agreements (see Bir and Sherman 2002). The interference of the military in politics on February 28, 1997, showed the apparent power of the military in this process. These demonstrate that the military not only pressured the government and restrained diplomatic capability but also sometimes undertook a foreign policymaker role to sustain the security-oriented policy.

Turkey's economic capacity was damaged by the severe economic crisis of 1994 , causing a more than five per cent decline in the GDP and a dramatic rise in inflation and unemployment rates (Köse and Yeldan 1998: 51). Although the economy showed growth in terms of the GDP in the following years, the repercussions of this crisis and political 
instability did not permit Turkey to expand its economic capacity. Eventually, this process ended up in another major financial crisis in 2001. The diplomatic capacity of Turkey and its credibility to act as a facilitator in the region remained low in this period. Regionally, its close ties with Israel drew harsh criticism and reaction from Arab countries amid the negative reflections of the previously mentioned security issues with Iraq, Syria and Iran. The international dimension can be analysed via the EU's perspective towards Turkey at this time. Although Turkey became a part of the Customs Union in 1996, it was sharply criticised by the EU for the poor democratic conditions in the country, such as the pressures on proKurdish political parties, the violations of human rights related to unidentified murders and the 'Anti-Terror Law' to deal with the PKK - even though it was modified in 1995 (Hale 2013: 176-177). Lastly, the crisis between Turkey and the EU peaked with the 1997 Luxembourg Summit when Turkey was not listed among the candidate countries. Turkey reacted to this summit by freezing its diplomatic ties with the EU.

Concerning its mediation initiatives in this period, Turkey undertook facilitator roles in three conflicts. Apart from two facilitation attempts in the Balkans to resolve the crisis between the Moldavian government and the Gagauzs and to bring the Croatian and Bosnian forces to the table during the civil war in Yugoslavia, the only initiative in the Middle East was to mobilise the neighbouring countries of Iraq to prevent potential intervention by the US. However, this initiative failed due to the unwillingness of the Iraqi side to negotiate with Turkey.

To sum up, these factors demonstrate that the security concerns of Turkey against the Middle East, most notably in its relations with neighbouring countries, were high during these five years. There was also a high level of domestic institutional constraint by the military. The military restrained foreign policy framework and acted as a foreign policymaker prioritising a security-oriented approach rather than showing any eagerness to pursue diplomatic expansion. Consequently, Turkey's activeness as a mediator remained very low. It only made one attempt to undertake a mediator role in the region, which ended in failure.

\section{b) Mitigating Security Concerns and the Pursuit of Diplomatic Expansion (1999-2002)}

The last two years of the 1990s witnessed significant events in the Middle East that paved the way for the desecuritisation process of Turkey's foreign policy in the first decade of the new century. In addition to the EU's recognition of Turkey as an official candidate in December 1999, significant regional changes and their reflections on Turkey's attitudes to countries in the region led to a change in Turkey's foreign policy at the turn of the century.

In the context of the legacy of the 'two and a half war strategy' inherited from the previous period, following Turkey's pressures on Syria by deploying troops along the Syrian border and signalling for a potential military conflict, Egypt adopted the facilitator role between the parties. As a consequence of these attempts, Syria deported the PKK leader Öcalan and an agreement was concluded between the parties in Adana in October 1998. The normalisation of relations gained momentum when Bashar Assad - who sought to adopt a foreign policy aiming to follow a more pragmatic and closer line in its relations with the West and Turkey - became the president of Syria (Aras and Polat 2008: 509-510). Turkey, in 
return, showed its willingness to mend ties with Syria. As a sign of this intention, the newly elected President Sezer paid his first official visit to Syria to attend the funeral of Hafez alAssad in 2000 (Altunışık and Tür 2006: 238-239).

Even though Greece is not in the Middle East, its close ties and, to some extent, its alliance with Syria made it an important player for those who seek to analyse Turkey's security agenda in this region, as it appears in the 'two and a half war doctrine' of Elekdağ. Moreover, after Öcalan had fled Syria and moved between several countries, his last destination was the Embassy of Greece in Nairobi, where he was captured on February 15, 1999. Despite all these developments that increasingly strained relations between the two countries, because the PKK leader was captured and relations with Syria began to recover, Greece ceased to be a threat against Turkey in Syria and finally in the Middle East. Besides, the rapid reciprocal responses of both countries' aid teams to the earthquakes in Turkey and Greece that occurred within thirty days provided a basis for the amelioration of relations, which enjoyed a peak in this period due to the efforts of the foreign ministers of both countries, Cem and Papandreou (Hale 2013: 196-198).

The PKK, on the other hand, declared a unilateral ceasefire that would last almost five years after the capture of Öcalan in 1999. Although the terrorist attacks of the PKK did not end completely, there was a dramatic decrease, particularly compared to the 1990s, throughout this ceasefire (see Şener 2010). The strategic partnership with Israel, which was mainly based upon the common threat perceptions of parties, began to lose its importance due to the de-escalating developments in Turkey's neighbourhood that reduced its security concerns. Additionally, the intensified Israeli attacks causing the deaths of hundreds of Palestinians following the outbreak of the Second Intifada strained Turkish-Israeli ties at the beginning of the century (Tür 2012: 52).

Lastly, Turkish-Iranian relations began the process of recovery in this period. Indeed, some problems regarding religious fundamentalism or radical Islamism that returned to the agenda of Turkey after the assassination of several intellectuals and the emergence of radical groups such as Turkish Hezbollah, as well as several issues that occurred between the countries following the capture of PKK's leader and accordingly Turkey's concerns about 'whether Iran has replaced Syria' strained the ties between Turkey and Iran in 1999 (Çetinsaya 2003: 159-160). Nevertheless, the transformation of the foreign policy visions of both countries, thanks to the structural alterations in the region and the willingness of leaders for rapprochement in both Iran and Turkey, formed a basis for the recovery of ties. While President Sezer and Foreign Minister Cem declared Turkey's desire to contribute to appeasement in the region, President Khatami's 'détente' policy prioritising intensified cooperation over the traditional mission of exporting the revolution indicated Iran's intention to normalise and 'rationalise' relations (Sinkaya 2012: 139; Çetinsaya 2003: 161).

Being the primary foreign policymaker in this period, İsmail Cem played a major role and contributed considerably to this reconciliation process with neighbouring countries. On the one hand, Cem pursued enhanced ties with the EU that had already begun to improve following the Helsinki Summit in 1999 and tried to expand and enlarge Turkey's diplomatic capacity by incorporating, for instance, African and even Latin American dimensions. Moreover, Cem sought to make Turkey a dynamic and energetic player in the Middle East by criticising Turkey's traditional relatively passive attitude towards developments in this region 
(Dündar 2015: 206). Additionally, Cem put forward that Turkey should go beyond another traditional attitude of embracing the bridge metaphor and instead seek to become a destination country (Altunışık 2009: 185). His initiatives to normalise the strained ties with the neighbouring countries and to enhance the country's image regionally by actively participating, for example, in the meetings of the Organisation of Islamic Cooperation and even internationally by convening a forum between the EU and the OIC (Organisation of Islamic Cooperation) as a response to the effect of September 11 and the so-called Clash of Civilisations discourse were signs of his willingness to extend Turkey's diplomatic sphere of activity (Altunış1k 2009: 186-187).

The restraining influence of the military over the government decreased comparatively in this period as the security threats against Turkey relatively reduced and thanks to the reform packages dictated by the EU, which ensured more power to the government to the detriment of the military in politics, for the accession process (Hale 2013: 181-182). Nevertheless, it is hard to expect such an immediate change and to argue that the military went out of the picture in foreign policymaking completely. More accurately, the military continued to function as an essential policy restrictor, if not as an essential policymaker in this period. Additionally, the crises between the presidency and government, among the parties in the coalition and even within the parties themselves played restrictive roles over the foreign policymakers' might.

While the economic capabilities of Turkey faced deep deterioration due to the two severe economic crises and the eventual bankruptcy of the banking system, its diplomatic capabilities enjoyed an expansion and improvement regionally and internationally thanks to the attempts of ameliorating ties with regional countries, more actively attending regional organisations, and enhancing ties with the EU and the US in this period. Concerning the economic might, following the economic crisis in November 2000, the intertwining of the crisis between the president and the government with the fragility of the economy caused a severe economic crisis in February 2001, which was the worst since the war, adversely influencing Turkey's economic leverage (Öniş 2003: 14-18).

Despite all the efforts and relative successes in implementing diplomatic expansion, mediation did not become a frequently used foreign policy tool between 1999 and 2002. As to activeness as a peace broker in the region, foreign minister Cem and his Greek counterpart sought to undertake a facilitator role between the parties in the Israeli-Palestinian crisis, and Turkey took some steps to reduce the tension in Iraq. However, both efforts eventually failed. Lastly, although it is not technically regarded as a mediation initiative, the 'OIC-EU Joint Forum: Civilisation and Harmony', as a response to September 11, was an important step for Turkey in its intention to enhance its diplomatic might. As will be discussed in the next section, it pioneered Turkey's 'Alliance of Civilisation' initiative in 2005.

To sum up, the developments in the region, mainly regarding the PKK and the neighbouring countries provided an environment for Turkey to transform its security-oriented attitude into a policy aiming to normalise its ties with the neighbouring countries. Security concerns reduced between 1999 and 2002. While foreign policymakers' willingness for diplomatic expansion increased remarkably, the level of domestic institutional constraint witnessed a partial decrease despite the ongoing presence of the military's effect on the government's elbow room and reflections of the crises inside the coalition government on 
foreign policymaking. A rise in Turkey's overall capacity for being a mediator showed itself in this period; its diplomatic capacity advanced considerably, whereas its economic capacity continued to suffer from economic crises even worse than in the previous period. Lastly, the activeness of Turkey as a mediator remained low in this period despite partial progress compared to the previous period.

\section{c) Under the Influence of the Zero Problems with Neighbours Doctrine (2003-2007)}

The structural repercussions of the September 11 attacks for Turkey's relations with the Middle East revealed themselves after the United States intervened in Iraq in 2003. As a large-scale analysis regarding the changing dynamics after the war, the vacuum of power stemming from this intervention provided the opportunity for Turkey and Iran, two neighbours of Iraq seeking to acquire a regional player role, to extend their sphere of influence in the region (Altunışık and Martin 2011: 576-577; Karacasulu and Aşkar 2011: 114). The activeness of these countries for the last two decades may be interpreted as a sign that both have utilised this opportunity.

Concerning this study's independent variable, the central reflection of these developments was that the PKK pursued consolidating its power in Northern Iraq utilising this vacuum in the region (Alptekin and Köse 2018: 319). Eventually, the PKK broke its ceasefire in 2004. However, unlike in the 1990s, the PKK problem did not drag Turkey's relations with neighbouring countries into a crisis. Rather, Turkey and Iran agreed to collaborate against the PKK and its offshoots, especially following the establishment of the PJAK as the offshoot of the PKK in Iran (Altunışık and Martin 2011: 576). Additionally, while the newly formed Iraqi government regarded the PKK as a threat against its territorial integrity, Syria did not intend to risk its improving relations with Turkey in this process. Thanks to all of these factors, as will be discussed below, what forged the central dynamics of Turkey's approach to the region in this period were not the concerns and hesitations about security; instead, it was the desire for diplomatic and economic expansion and cooperation.

In domestic politics, Prime Minister Erdoğan and Foreign Minister Gül undertook important roles as foreign policy practitioners. Also, Ahmet Davutoğlu, who occupied the position of chief foreign policy advisor to the prime minister, is depicted in the literature by some as the architect of the foreign policy vision of the AKP (Aras 2009; Altunış1k 2009). The assessments and perspectives of Davutoğlu on Turkish foreign policy are conceptualised as 'strategic depth', referring to his book of 2001. In this book, Davutoğlu firstly formulates a power equation model and then analyses Turkey's relative power and position in international politics according to this model in detail. This model incorporates various dimensions and levels of analysis into the equitation by including, on the one hand, static parameters (history, geography, population and culture) and potential parameters (economic, technological and military capacity) and, on the other hand, strategic mind-set, strategic planning and political will (Davutoğlu 2001: 17). Referring to this model, Davutoğlu describes a political vision pursuing a high level of diplomatic expansion for Turkey into various regions.

In a similar vein to İsmail Cem, Davutoğlu brings criticism to the traditional Turkish foreign policy towards the Middle East and embraces a critical approach to the bridge 
metaphor by naming Turkey's potential role as a 'central' state (Davutoğlu 2013a: 77-86). In this respect, Davutoğlu utilises some concepts and doctrines to characterise his foreign policy approach, such as 'zero problems with neighbours', 'rhythmical diplomacy' and 'multidimensional foreign policy’ (Davutoğlu 2013a: 113-117), all of which strongly point to a willingness for diplomatic expansion.

The results of the 2002 elections enabled the AKP to form a government without needing a coalition partner, providing an opportunity for the government to pursue its foreign policy goals without facing restrictions from, for instance, the parties within the coalition as seen in the previous period. In the context of the military's traditional influential effect on politics, the EU process and reform packages passed as a consequence weakened its impact, mainly due to reforms within the National Security Council reducing the influence of the military and transforming its structure in favour of the elected government (Aydin and Aç1kmeşe 2007: 269). Nevertheless, it is hard to say that the impact of the military was completely diminished in this period, considering, for example, the military's explicitly declared opposition and criticisms of the government during the Annan Plan process for Cyprus and, more importantly, the so-called E-memorandum of April 2007.

Turkey's diplomatic and economic capacity increasingly advanced in this period. In terms of its diplomatic capacity, the refusal of the memorandum to allow US troops to use Turkish soil during the intervention by parliament in 2003 improved Turkey's image and credibility in the region (Altunışık 2008: 49). With respect to the AKP's Islamist origins, its transformation into a conservative democrat line, as argued by AKP's leaders, and the success of the AKP in terms of democratisation and economic growth during this period, contributed much to its image and diplomatic power (Altunışık 2008: 44). In this context, the election of Ekmeleddin İhsanoğlu to the position of Secretary-General of the OIC is an indicator of Turkey's rising diplomatic capacity and activeness in the region (Oğuzlu 2007: 90).

Within the EU dimension, after Turkey was recognised as a candidate state in 1999 and fulfilled a set of political criteria within the process, accession negotiations began in 2005 . This process provided an environment for Turkey to improve its diplomatic might in both the Middle East and Europe at the same time without disassociating itself from either of them (Oğuzlu 2008: 17). Lastly, despite escalated tensions between Turkey and the US after the parliamentary rejection of the memorandum in 2003 and because of Turkey's increasingly recovering and intensifying contacts with Iran and Syria that were on the so-called 'axis of evil' list of President Bush, relations with the US began to recover as a result of diplomatic efforts of both sides. Significant steps were taken to consolidate the strategic partnership between the parties after 2004 (Türkmen 2009).

Unlike the previous period, Turkey's economic capacity increased in accord with its diplomatic capacity. Turkey successfully overcame the repercussions of the two severe economic crises of 2000 and 2001 and achieved significant economic growth, substantially increasing its trade volume with the Middle East (Tür 2011: 592-593). The trade volume between Turkey and the Middle East was $\$ 6.2$ billion in 2002, this number increased to $\$ 27.7$ billion in 2007. The share of the Middle East in Turkey's total trade volume increased from 8.49 per cent to 10 per cent between 2003 and 2007 (Tür 2011: 592-593). Kirişçi (2009) described Turkey as a rising 'trading state' considering that economic considerations began to 
occupy an increasingly important place in Turkey's foreign policy and, more importantly, in its ties with neighbouring countries.

In the Middle East, Turkey actively resorted to mediation and undertook facilitator roles in various conflicts in this period: the Initiative of Neighbouring Countries of Iraq that lasted between 2003 and 2008 and successfully brought various players to the table; facilitation between Sunni and Shiite groups in Iraq to provide a convenient environment for the parties seeking to establish contacts with each other for the upcoming elections in 2005; the arrangement of the first official meeting ever between Israeli and Pakistani foreign ministers in İstanbul in 2005; facilitation efforts between Israel and Lebanon in the 2006 crisis; the 2007 meeting series in Istanbul to bring politicians and business people from Israel and Palestine for dialogue and cooperation; mediation in hostage crises between Hamas and Israel in 2006 and the United Kingdom and Iran in 2007 and lastly, pioneering the initiative of the Alliance of Civilizations with Spain in the UN.

To sum up, although the PKK broke the ceasefire and sought to consolidate its power in Northern Iraq, since all neighbouring countries perceived a potential rise of the PKK as a threat to themselves, this development did not lead Turkey to embrace a foreign policy guided by security concerns in its relations with the region. Therefore, the level of security concerns remained low in this period. Foreign policymakers adopted an active foreign policy and explicitly showed eagerness for diplomatic expansion. The constraint of domestic institutions, especially the military, began to lose its influence. Also, both Turkey's diplomatic and economic capacities increased considerably. Finally, Turkey's activeness as a peace broker rose significantly during this period.

\section{d) Turkey: A Model Country? (2008-2011)}

Turkey's relations with its three neighbours in the Middle East continued to take shape mostly around dialogue and cooperation instead of security-oriented concerns and conflicts until the second half of 2011, when the emergence of turmoil developed out of the Arab uprisings in the region. The PKK remained the main security problem of Turkey but did not cause any deterioration in Turkey's ties with its neighbours as in the previous period. Rather, it even allowed these countries to cooperate against the PKK in some cases. In this period, Turkey's ties with Iran and Syria continued with the cooperation or at least non-intervention principle regarding the PKK. In this sense, Turkey abandoned its sceptical approach to the Kurdistan Regional Government in Northern Iraq and intensified its relations with both the central government of Iraq and the Kurdistan Regional Government over various issues, including the PKK (Barkey 2011: 663). However, this period witnessed to a severe worsening of Turkish-Israeli relations because of the Israeli attack on Gaza in November 2008, the 2009 Davos crisis and the Mavi Marmara Incident in 2010, although diplomatic contacts between these two countries had flourished during Turkey's entire facilitation attempts for the conflict between Israel and Syria throughout almost all of 2008. Nonetheless, the escalated tensions with Israel did not lead Turkey to prioritise a security-oriented attitude towards the broader region. 
Davutoğlu and Erdoğan were key figures in managing Turkey's foreign policy during this period. Davutoğlu, who mainly contributed to foreign policy as a theoretician in the previous term, became the Foreign Minister in 2009 and delivered a highly energetic performance in this period. It was clear that Davutoğlu played the leading role in Turkey's engagement in active diplomacy policy and, accordingly, Turkey's enthusiasm to undertake mediator roles in the various conflicts in different regions (see, for instance, The Economist 2010). Erdoğan, on the other hand, maintained his influential role as an implementer. For example, Erdoğan demonstrated a critical effort to bring Israeli and Syrian leaders to the table and sustain dialogue between the parties in 2008.

Following the e-memorandum of the military in 2007 and the closure case of the AKP in 2008 signalling possible political instability (Aydın-Düzgit 2012: 331-333), the AKP consolidated its power in domestic politics through victories in all presidential, general and municipal elections, the Ergenekon trials and the constitutional referendum seeking to weaken the leverage of the military and judiciary on politics. As an overall analysis of this period, the AKP eventually succeeded in intensifying civilian control of domestic politics and reinforcing the government's power in foreign policymaking.

The development of Turkey's diplomatic capacity for pursuing expansion that had already gained momentum in the previous period remained high within these years. Apart from its intensifying diplomatic convergence with countries in the region, Turkey enhanced its image among Arab peoples, which had also been rising in the previous period, especially after the crisis between Israel and Turkey. Turkey's attitude regarding the Israeli-Palestinian conflict, best characterised by the 2009 Davos incident, contributed significantly to Turkey's rising status in the Middle East.

TESEV carried out a project to measure Turkey's image in the Middle East by conducting interviews in seven countries in the region in 2009. This project continued until 2013, increasing the number of participating countries each year. The reports from 2009, 2010 and 2011 show that over 70 per cent of the interviewees considered Turkey an important contributor to peace in the region, and over 60 per cent in all three reports saw Turkey as a model in the region. More than 75 per cent of the interviewees expressed positive opinions about Turkey in all reports. Even, the report of 2011 placed Turkey top of that category with 78 per cent, the only country with more than 70 per cent (Akgün et al. 2010; Akgün et al. 2011; Akgün and Senyücel Gündoğar 2012). The rich literature about the Turkish model in the Middle East, particularly after the uprisings (see Göksel 2012; Dede 2011) and the statements from prominent political figures who played important roles in their countries during and after the uprisings (Dünya 2012; Göksel 2014; Hürriyet Daily News 2011) illustrate the rising trend of the Turkish model in the Arab world.

Even though Turkey's membership negotiations with the EU started to face problems, the positive approach of the European Union and the United States to the democratic and secular Turkish model contributed to the rising image of Turkey in the international arena during this term. Lastly, as an important indicator of its internationally rising image, Turkey was elected to the UN Security Council in 2008 for the term of 2009-2010, receiving votes from 151 countries out of 192, well above the required two-thirds majority.

Although the 2008 global economic crisis had a severe influence on the Turkish economy and negatively affected Turkey's economic growth and foreign trade volume, 
Turkey achieved economic recovery within a short period. Growth in both of the indicators began again in 2010. Turkey continued to enhance its economic relations with the Middle East by initiating projects with neighbouring countries such as the 'East Mediterranean Four: Levant Business Forum' that sought to become the first steps in enabling a 'Customs Union' of the Middle East by including new domestic players in this economic expansion process such as MÜSİAD and TUSKON (Tür 2011: 592-597).

This period witnessed a highly active Turkey in terms of undertaking a mediator role, not just in the Middle East but also in other regions and within the UN. In these four years, Turkey played mediator roles in the following crises and circumstances in the Middle East: facilitation in the conflict between Israel and Syria in 2008 that consisted of longstanding issues such as the control of the Golan Heights; contribution to the Doha Agreement that aimed to bring the political parties in Lebanon together in 2008; facilitation between Israel and Palestine in 2008; mediation efforts with Brazil to resolve the nuclear energy crisis between Iran and the P5+1 countries in 2009 and 2010; facilitation between Iraq and Syria and Saudi Arabia and Syria in 2009; mediation between Shiite and Sunni parties in Iraq in 2010; another attempt to bring the parties of Lebanon together in 2011 and mediation in the hostage crisis for the release of French citizen Clotilde Reiss between Iran and France.

Turkey also undertook a mediator role in the crises immediately after the beginning of the uprisings in 2011: contribution to facilitation between protestors and the government in Bahrain; facilitation between the government of Qaddafi and protestors in Libya; facilitation between Sunni leaders in Iraq; facilitation between Shiite and Sunni Turkmen groups in Iraq; mediation for the release of four New York Times journalists and then for one Guardian journalist in Libya.

To summarise, Turkey's foreign policy in the Middle East was not driven by securityoriented hesitations in this period. Thus, the level of security concerns was low. Like the previous period, key figures in foreign policy-making demonstrated their willingness for diplomatic expansion. Also, the level of domestic institutional constraint decreased significantly. While Turkey's diplomatic capacity continued to follow a rising trend, its economic capacity remained relatively high despite the severe ramifications and repercussions of the 2008 economic depression. Finally, the activeness of Turkey as a mediator enjoyed its peak in this period.

\section{e) Earthquake in the Region: Security Again? (2012-2016)}

In one of his articles, Davutoğlu (2013b) stresses three global developments that led to earthquake-like effects on the international order and Turkish foreign policy. In addition to the end of the Cold War and 9/11, the third earthquake was the 2008 economic crisis and, as its regional reflection, the Arab Uprisings. The uprisings, which broke out in Tunisia in December 2010 and spread to other Arab countries at a great pace, influenced Turkey and, thereby, its soft-power capability towards the region considerably. Regarding its security concerns towards the region, since the second half of 2011, Turkey's relations with its neighbours that had been driven by desecuritisation and cooperation were replaced by increasingly rising security and conflict-based problems. 
Although Turkey conducted an intensified diplomacy to prevent a possible domestic conflict and eventually a civil war within Syria and for that purpose Foreign Minister Davutoğlu maintained his dialogue with President al-Assad until August 2011 in order to convince him of a reform package, it then has positioned itself against the Syrian government, whose relations with Turkey had been enjoying a growing trend since the beginning of the century, as the calls for reform remained unanswered (Han 2016: 67). Afterwards, Turkey decided to support the opposition groups against the Syrian government. The PYD, the Syrian extension of the PKK, took advantage of the vacuum of power in Northern Syria and consolidated its dominance in the region. ISIS also expanded into a considerably broader area in Syria and Iraq thanks to the turmoil in the region, launching several terrorist attacks on the Turkish military and civilians inside and outside of Turkey. More importantly, Russia became a crucial player in the region as the supporter of the Syrian regime, and the oscillating ties between Turkey and Russia faced severe deterioration after the Jet crisis in 2015. Lastly, it became harder for Turkey to ensure the security of the Syrian borders because of the influx of refugees from Syria to Turkey.

The American withdrawal, which was a structural development for the region's future, allowed Iran to extend its sphere of influence into Iraq freely. First, the deployment of NATO radar in 2011 and patriot batteries in 2012 in south-eastern Anatolia and Iran's support for the Syrian regime strained Turkish-Iranian relations (Ayman 2014: 20). Then, the increasing tension in Turkish-Iranian relations redounded negatively on Turkish-Iraqi relations. Finally, the outbreak of the Iraqi civil war in 2014 led Turkey to take more security measures against Iraq. The official Kurdish opening process that decreased the tension between Turkey and the PKK only lasted two years. After PKK's attacks, Turkey restarted the war on the PKK terror in the summer of 2015.

Prime Minister/President Erdoğan and Foreign Minister/Prime Minister Davutoğlu assumed key roles in foreign policymaking as they did in the previous period. Though the foreign policy doctrines of Davutoğlu, such as the zero problems with neighbours policy, seemed to lose their effectiveness because of the structural developments and Turkey's reactions to them, Turkey did not abandon its active diplomacy in the region and sought to maintain its willingness to be a regional player. As Keyman argues, Turkey adopted a 'moral realist' policy composed of resorting to both hard power as a realistic move because of the increasing security concerns and humanitarian assistance as the moral part (Keyman 2017). Besides, Turkey's domestic politics and especially the government faced some severe crises during this period, such as the Gezi protests, the corruption allegations, a short-term government formation crisis during the summer of 2015 and finally, a coup attempt in July 2016. Despite all these serious crises, the government remained the central player in foreign policymaking without facing any significant domestic institutional constraint.

As noted above, the central doctrines of Turkish foreign policy that had been followed during the last decade lost their effectiveness following the Arab uprisings, its structural repercussions and Turkey's attitudes and reactions towards these developments. As Öniş (2012) noted, the outbreak of the protests in Arab countries against the authoritarian regimes brought a dilemma between national interest and ethics to the Turkish foreign policy agenda as to whether it would maintain its positive ties with the existing regimes or support the 
protestors. Turkey opted for the latter and supported opposition groups in Tunisia, Egypt, Libya and Syria.

However, the process did not go as Turkey expected considering the ongoing civil wars in Syria and Libya or the failure of democracy in Egypt. In addition to the deteriorating relations with its neighbours, Turkey's ties with Egypt witnessed a breakdown following its harsh criticism of the military coup in 2013. This process negatively affected Turkey's relations with countries such as the United Arab Emirates and Saudi Arabia, which assertively sided with Egypt's new regime. All these caused a weakening of Turkey's diplomatic capacity and credibility in the region compared to the previous two periods. According to TESEV's last report about perceptions on Turkey in the Middle East, Turkey had been placed top in 2011 and 2012 but fell to third place on the list of the most highly regarded countries in the region in 2013 (Akgün and Senyücel Gündoğar 2013: 8). Moreover, the Turkish model began to lose its effectiveness because of both the worsening ties with countries in the region and Turkey's own domestic problems regarding its democracy. (Taşpınar 2014).

Alongside the economic instability in Turkey, especially after 2013, the worsening diplomatic relations with the regional countries and the fall of crude oil prices in 2014 caused a fluctuation in trade volume between Turkey and the Middle East (Öztürk 2018: 894-895). However, Turkey did not face a significant decline in its economic capacity considering the whole process and did not witness a major economic crisis as in 2001, mainly due to the successful growth of the Turkish economy in 2012 and 2013.

The turmoil in the region and the conflicts stemming from it provided a suitable environment for the countries aiming to pursue an active peace broker role. In the first half of 2011, Turkey assumed facilitator roles in Libya, Bahrain, Lebanon and Iraq, as noted in the previous section. However, Turkey could not participate as a facilitator in any conflict in the Middle East, although it attempted to undertake such a role in some cases. For instance, when tension escalated between Israel and Palestine in 2014, Turkey tried to assume a mediator role as it had many times before between these two parties. However, Turkey's mediation proposal was rejected by the conflicting parties, and Egypt undertook the broker role in this crisis instead of Turkey (Gümüşçü 2016: 48-50). Though Turkey played a facilitator role in several non-Middle Eastern conflicts such as Somalia in 2013, between Afghanistan and Pakistan until 2014 and the Philippines in 2012 and 2016 and initiated mediation conference series such as the Istanbul Mediation Conference since 2012 and Friends of Mediation Groups in the OSCE first held in 2014, it did not or more precisely could not undertake a mediator role in the Middle East in this period.

Turkey's security concerns towards the region, especially in its neighbourhood, increased significantly in this period. Despite some difficulties in applying the foreign policy doctrines of the 2000s, the key players in foreign policymaking continued to have a high level of enthusiasm for diplomatic expansion while domestic institutional constraints remained very low. Turkey's capacity, which was at its peak in the previous period, relatively regressed during this process, especially in terms of its diplomatic capacity. The level of Turkey's activeness as a mediator was very low in this period. 


\section{Findings and Conclusion}

This study sought to investigate the main factors behind Turkey's varying level of activeness as a mediator in the Middle East during the post-Cold War era. By considering the analyses of the levels of variables, the following evaluations can be made around each variable. For the level of security concerns of Turkey towards the Middle East, as the independent variable, the analysis shows that whereas it was high throughout the periods of 1994-1998 and 20122016, the periods of 1999-2002, 2003-2007 and 2008-2011 witnessed low levels of security concerns.

Investigating the eagerness of foreign policymakers for diplomatic expansion, the first intervening variable, determines that its level was low during 1994-1998. However, in the remaining periods, the foreign policymakers, particularly İsmail Cem and Ahmet Davutoğlu, demonstrated a high level of willingness to expand Turkey's diplomatic sphere of influence, not only in the Middle East but also in other regions, in their written works, interviews, speeches and most importantly in their implementations. Analysis of domestic institutional constraint, the second intervening variable, reveals that domestic institutional constraint was very high between 1994-1998. The constraint followed a steadily declining trend throughout the subsequent periods and finally reached a very low level in the last two periods.

Lastly, while Turkey's diplomatic and economic capacity, the third intervening variable, was low between 1994-1998, the next period witnessed a considerable rise in its diplomatic capacity despite the deteriorated economic conditions and severe economic crises. During the periods of 2003-2007 and 2008-2011, Turkey's diplomatic and economic capacity showed a remarkable advancement. However, while its diplomatic capacity underwent a deterioration process, Turkey's economy did not face such a significant deterioration between 2012 and 2016, although it could not achieve the success of the previous two periods.

With respect to Turkey's activeness as a mediator in the Middle East, the dependent variable, the analysis reveals that Turkey showed a very low level of activeness in the periods of 1994-1998 and 2012-2016, during which it did not or could not carry out any successful mediation. Between 1999-2002, Turkey's activeness remained low, but Turkey's facilitation between Israel and Palestine and also the comprehensive and unprecedented attempts that provided a background for further mediation initiatives such as the 'OIC-EU Joint Forum: Civilisation and Harmony' demonstrated that Turkey pursued a more active policy as a mediator in this period compared to the previous term. Lastly, this activeness followed a continuously increasing trend during the following two periods reaching its peak between 2008-2011, during which time Turkey undertook a facilitator role in several conflicts between and within various countries.

Table 3 below illustrates the completed version of the theoretical model of this study showing the values of the variables' levels during the specified periods. 
Table 3. Theoretical Model and Periodisation (Completed)

\begin{tabular}{|c|c|c|c|c|c|}
\hline \multirow{2}{*}{ Periods } & $\begin{array}{c}\text { Independent } \\
\text { Variable }\end{array}$ & \multicolumn{3}{|c|}{ Intervening Variables } & $\begin{array}{c}\text { Dependent } \\
\text { Variable }\end{array}$ \\
\cline { 2 - 6 } & $\begin{array}{c}\text { Security } \\
\text { Concerns }\end{array}$ & $\begin{array}{c}\text { Foreign } \\
\text { Policymakers } \\
\text { Perceptions } \\
\text { (eagerness for } \\
\text { diplomatic } \\
\text { expansion) }\end{array}$ & $\begin{array}{c}\text { Domestic } \\
\text { Institutional } \\
\text { Constraint } \\
\text { (Pressure of } \\
\text { Military or } \\
\text { Coalition } \\
\text { Parties) }\end{array}$ & $\begin{array}{c}\text { Capability/Capacity } \\
\text { (Diplomatic and } \\
\text { Economic) }\end{array}$ & $\begin{array}{c}\text { Activeness } \\
\text { as a } \\
\text { Mediator }\end{array}$ \\
\hline $\begin{array}{c}\mathbf{1 9 9 4} \\
\mathbf{1 9 9 8}\end{array}$ & High & Low & Very High & Low & Very Low \\
\hline $\begin{array}{c}\mathbf{1 9 9 9}- \\
\mathbf{2 0 0 2}\end{array}$ & Low & High & High & Medium & Low \\
\hline $\begin{array}{c}\mathbf{2 0 0 3}- \\
\mathbf{2 0 0 7}\end{array}$ & Low & High & Low & High & Very High \\
\hline $\begin{array}{c}\mathbf{2 0 0 8}- \\
\mathbf{2 0 1 1}\end{array}$ & Low & High & Very Low & High & Vow \\
\hline $\mathbf{2 0 1 2 -}$ \\
$\mathbf{2 0 1 6}$
\end{tabular}

In the light of the analysis and the table created as an outcome, this article has reached the following conclusions. First and foremost, the values indicate that when Turkey's security concerns towards the region are high, its activeness as a mediator is very low. In other words, high values in the level of the independent variable cause very low values in the dependent variable. The values of these variables in the periods of 1994-1998 and 2012-2016, during which the values of the independent variable were high whereas the values of the dependent variable were very low despite the clear dissimilarities between the values of the intervening variables when comparing these two periods, demonstrate this relationship.

Secondly, however, the aforementioned relationship between these two variables does not necessarily mean that low values of the independent variable automatically lead to high values for the dependent variable's level. Instead, the intervening variables come into play at this stage. The analysis demonstrates that when security concerns towards the region are low, the values of the intervening variables should be examined. In this case, the table shows that the more eagerness of foreign policymakers for diplomatic expansion, the less domestic institutional constraint and the more capacity or capability result in more activeness as a mediator. As an example from the table, Turkey enjoyed its peak in terms of the level of activeness in the 2008-2011 period when, alongside low security concerns, foreign policymakers' eagerness for diplomatic expansion and capacity were high and domestic 
institutional constraint was low. However, despite the low level of security concerns towards the Middle East and the high level of willingness of foreign policymakers for diplomatic expansion between 1999 and 2002, the level of activeness was still low because of the high level of domestic institutional constraint and relatively low level of capacity.

In conclusion, investigating this process through these variables, this article has reached the following two conclusions regarding Turkey's activeness as a mediator in the Middle East in the post-Cold War era: (1) when the security concerns increase, the activeness declines. (2) When security concerns decrease, the levels of intervening variables determine the degree of activeness. This conclusion has potential implications for the foreign policy behaviour of countries other than Turkey and future comparative studies on various empirical cases may help us effectively theorize foreign policy-making and mediation activeness.

\section{References}

Akgün, Mensur, Gökçe Perçinoğlu and Sabiha Senyücel Gündoğar (2009) Orta Doğu'da Türkiye Algısı (İstanbul: TESEV).

Akgün, Mensur and Sabiha Senyücel Gündoğar (2012) Orta Doğu'da Türkiye Algısı 2011 (İstanbul: TESEV).

Akgün, Mensur and Sabiha Senyücel Gündoğar (2013) Orta Doğu'da Türkiye Algısı 2013 (İstanbul: TESEV).

Akgün, Mensur, Sabiha Senyücel Gündoğar Jonathan Levack and Gökçe Perçinoğlu (2011) Orta Doğu'da Türkiye Algisı 2010 (İstanbul: TESEV).

Akpınar, Pinar (2015) 'Mediation as a Foreign Policy Tool in the Arab Spring: Turkey, Qatar and Iran', Journal of Balkan and Near Eastern Studies 17 (3), pp. 252-268. https://doi.org/10.1080/19448953.2015.1063270.

Alptekin, Hüseyin, and Talha Köse (2018) 'AK Parti'nin Kürt Politikası', in Nebi Miş and Ali Aslan (ed.) AK Parti’nin 15 Yllı (İstanbul: SETA), pp. 315-338.

Altunışı, Meliha Benli (2000) 'The Turkish-Israeli Rapprochement in the Post-Cold War Era’, Middle Eastern Studies 36 (2), pp. 172-191.

Altunışık, Meliha Benli (2008) 'The Possibilities and Limits of Turkey's Soft Power in the Middle East', Insight Turkey 10 (2), pp. 41-54.

Altunışık, Meliha Benli (2009) 'Worldviews and Turkish Foreign Policy in the Middle East', New Perspectives on Turkey 40, pp. 171-94.

Altunışık, Meliha Benli and Esra Çuhadar (2010) 'Turkey's Search for a Third Party Role in Arab-Israeli Conflicts: A Neutral Facilitator or a Principal Power Mediation', Mediterranean Politics 15 (3), pp. 371-392. https://doi.org/10.1080/13629395.2010.517101. 
Altunışık, Meliha Benli, and Lenore G. Marti (2011) 'Making Sense of Turkish Foreign Policy in the Middle East under AKP', Turkish Studies 12 (4), pp. 569-87. https://doi.org/10.1080/14683849.2011.622513.

Altunışık, Meliha Benli, and Özlem Tür (2006) 'From Distant Neighbors to Partners? Changing Syrian-Turkish Relations', Security Dialogue 37 (2), pp. 229-48. https://doi.org/10.1177/0967010606066172.

Aras, Bülent (2014) 'Davutoğlu Era in Turkish Foreign Policy Revisited', Journal of Balkan and Near Eastern Studies 16 (4), pp. 404-18. https://doi.org/10.1080/19448953.2014.938451.

Aras, Bülent (2009) 'The Davutoğlu Era in Turkish Foreign Policy', Insight Turkey 11 (3), pp. 127-42.

Aras, Bülent, and Rabia Karakaya Polat (2008) 'From Conflict to Cooperation: Desecuritization of Turkey's Relations with Syria and Iran', Security Dialogue 39 (5), pp. 495-515. https://doi.org/10.1177/0967010608096150.

Ayaz Avan, Esengül (2019) 'Europeanization of Turkey's Foreign Policy: The Case of Turkey's Mediation in the Israel-Palestine Conflict' Journal of Balkan and Near Eastern Studies 21 (6), pp. 678-95. https://doi.org/10.1080/19448953.2018.1506294.

Aydin-Düzgit, Senem (2012) 'No Crisis, No Change: The Third AKP Victory in the June 2011 Parliamentary Elections in Turkey', South European Society and Politics 17 (2), pp. 329-46. https://doi.org/10.1080/13608746.2011.640426.

Aydın, Mustafa, and Sinem A. Açıkmeşe (2007) 'Europeanization through EU Conditionality: Understanding the New Era in Turkish Foreign Policy', Journal of Southern Europe and the Balkans 9 (3), pp. 263-74. https://doi.org/10.1080/14613190701689944.

Barkey, Henri J (2011) 'Turkey and Iraq: The Making of a Partnership', Turkish Studies 12 (4), pp. 663-74. https://doi.org/10.1080/14683849.2011.622508.

Bercovitch, Jacob (2009) 'Mediation and Conflict Resolution', in Jacob Bercovitch, Kremenyuk Victor, and I William Zartman (ed.) The SAGE Handbook of Conflict Resolution (London: SAGE), pp. 340-58.

Bercovitch, Jacob, and Richard Jackson (2009) Conflict Resolution in the Twenty-First Century (Michigan: University of Michigan Press).

Beriker, Nimet (2016) 'United States's Grand Strategy and the Middle Power Policy: Turkey as a Mediator' in Doğa Ulaş Eralp (ed.) Turkey as a Mediator: Stories of Success and Failure (Lanham: Lexington Books), pp. 1-24.

Bir, Çevik and Martin Sherman (2002) 'Formula for Stability: Turkey Plus Israel', Middle East Quarterly, pp. 23-32.

Bonab, Rahman G. (2009) 'Turkey's Emerging Role as a Mediator on Iran's Nuclear Activities', Insight Turkey 11 (3), pp. 161-75. 
Çetinsaya, Gökhan (2003) 'Turkish-Iranian Relations since the Revolution', Turkish Review of Middle East Studies 14, pp. 143-61.

Çuhadar Gürkaynak, Esra (2007) 'Turkey as a Third Party in Israeli-Palestinian Conflict: Assessment and Reflections', Perceptions: Journal of International Affairs 12 (1), pp. 89-108.

Davutoğlu, Ahmet (2001) Stratejik Derinlik (İstanbul: Küre).

Davutoğlu, Ahmet (2013a) Teoriden Pratiğe: Türk Dış Politikası Üzerine Konuşmalar (İstanbul: Küre).

Davutoğlu, Ahmet (2013b) 'The Three Major Earthquakes in the International System and Turkey', International Spectator: Italian Journal of International Affairs 48 (2), pp. 111. https://doi.org/10.1080/03932729.2013.796781.

Dede, Alper Y. (2011) 'The Arab Uprisings: Debating the 'Turkish Model', Insight Turkey 13 (2), pp. 23-32.

Dündar, Can (2015) Ben Böyle Veda Etmeliyim, 3rd ed. (İstanbul: Can Yayınları).

Dünya (2012) 'Ennahda Leader Says Turks are Model, Inspiration for Tunisia', July 12. Available at: https://www.dunya.com/gundem/ennahda-leader-says-turks-are-modelinspiration-for-tunisia-haberi-179561.

Elekdağ, Şükrü (1994) ‘İki Buçuk Savaş Stratejisi’, Milliyet, December 2.

Engin Öztürk, M. Büşra (2018) 'Türkiye-Ortadoğu Ülkeleri Arasındaki Dış Ticaret ve Sermaye Hareketleri’, Uluslararası Sosyal Araştırmalar Dergisi 11 (60), pp. 894-908.

Fırat, Melek and Ömer Kürkçüoğlu (2001) 'Orta Doğu'yla İlişkiler: Arap Devletleriyle İlişkiler', in Baskın Oran (ed.) Türk Dış Politikası: Kurtuluş Savaşından Bugüne, Olgular, Belgeler, Yorumlar (İstanbul: İletişim), pp. 560-563.

Göksel, Oğuzhan (2014) 'Perceptions of the Turkish Model in Post-Revolutionary Tunisia’, Turkish Studies 15 (3), pp. 476-495.

Göksel, Oğuzhan (2012) 'Assessing the Turkish Model as a Guide to the Emerging Democracies in the Middle East', Ortadoğu Etütleri 4 (1), pp. 99-120.

Gümüşçü, Şebnem. 'Turkey's Peace Initiatives in the Middle East: A Tragic Turn of Events', in Doğa Ulaş Eralp (ed.) Turkey as a Mediator: Stories of Success and Failure (Lanham: Lexington Books), pp. 39-54.

Hale, William (2013) Turkish Foreign Policy since 1774, 3rd ed. (London: Routledge).

Han, Ahmet K (2016) 'Paradise Lost: A Neoclassical Realist Analysis of Turkish Foreign Policy and the Case of Turkish-Syrian Relations Ahmet', in Raymond Hinnebusch and Özlem Tür (ed.) Turkey-Syria Relations: Between Enmity and Amity (London: Routledge), pp. 55-70. 
Hürriyet Daily News (2011) 'Tunisian Runner-up Also Taking Turkey as a Model', October 31. Available at: https://www.hurriyetdailynews.com/tunisian-runner-up-also-takingturkey-as-model-6376.

Kaarbo, Juliet (2015) 'A Foreign Policy Analysis Perspective on the Domestic Politics Turn in IR Theory', International Studies Review 17 (2), pp. 189-216. https://doi.org/10.1111/misr.12213.

Karacasulu, Nilüfer and İrem Aşkar Karakır (2011) 'Iran-Turkey Relations in the 2000s: Pragmatic Rapprochement', Ege Akademik Bakis 11 (1), pp. 111-19. https://doi.org/10.21121/eab.2011119592.

Keyman, E. Fuat (2017) 'A New Turkish Foreign Policy: Towards Proactive 'Moral Realism', Insight Turkey 19 (1), pp. 55-69.

Kirişci, Kemal (2009) 'The Transformation of Turkish Foreign Policy: The Rise of the Trading State', New Perspectives on Turkey 40, pp. 29-57. https://doi.org/10.1017/s0896634600005203.

Köse, Talha (2013) 'Transformative Conflict Resolution in an Unstable Neighbourhood: Turkey's Conflict Resolution Efforts in the Middle East', Perceptions 18 (4), pp. 171-94.

Köse, Ahmet Haşim and A. Erinç Yeldan (1998) 'Turkish Economy in the 1990s: An Assessment of Fiscal Policies, Labor Markets and Foreign Trade', New Perspectives on Turkey 18, pp. 51-78. https://doi.org/10.1017/s0896634600002880.

Legro, Jeffrey W. and Andrew Moravcsik (1999) 'Is Anybody Still a Realist?', International Security 24 (2), pp. 5-55.

Mitchell, Gabriel (2015) 'Turkey: The Almost Mediator State', Turkish Policy Quarterly 14 (1), pp. 169-77.

Moravcsik, Andrew (1997) 'Taking Preferences Seriously: A Liberal Theory of International Politics', International Organization 51 (4), pp. 513-53.

Murinson, Alexander (2006) 'The Strategic Depth Doctrine of Turkish Foreign Policy', Middle Eastern Studies 42 (6), pp. 945-64. https://doi.org/10.1080/00263200600923526.

Oğuzlu, Tarık (2008) 'Middle Easternization of Turkey’s Foreign Policy: Does Turkey Dissociate from the West?', Turkish Studies 9 (1), pp. 3-20. https://doi.org/10.1080/14683840701813960.

Oğuzlu, Tarkk (2007) 'Soft Power in Turkish Foreign Policy', Australian Journal of International Affairs 61 (1), pp. 81-97. https://doi.org/10.1080/10357710601142518.

Öget, Mustafa (2019) 'Turkish Foreign Policy in Davutoğlu Era: A Critical Assessment', (MA Thesis: Sabanc1 University).

Öniş, Ziya (2012) 'Turkey and the Arab Spring: Between Ethics and Self-Interest', Insight Turkey 14 (3), pp. 45-63. 
Öniş, Ziya (2003) 'Domestic Politics versus Global Dynamics: Towards a Political Economy of the 2000 and 2001 Financial Crises in Turkey', in Ziya Öniş and Barry Rubin (ed.) The Turkish Economy in Crisis (London: Frank Cass), pp. 1-31.

Pipes, Daniel (1997) 'A New Axis: The Emerging Turkish-Israeli Entente', The National Interest 50, pp. 31-38.

Ripsman, Norrin M., Jeffrey W. Taliaferro and Steven E. Lobell (2009) eds. Neoclassical Realism, the State, and Foreign Policy (Cambridge: Cambridge University Press).

Ripsman, Norrin M., Jeffrey W. Taliaferro and Steven E. Lobell (2016) Neoclassical Realist Theory of International Politics (New York: Oxford University Press).

Rose, Gideon (1998) 'Neoclassical Realism and Theories of Foreign Policy', World Politics 51 (1), pp. 144-72.

S. Gülden Ayman (2014) 'Turkey and Iran: Between Friendly Competition and Fierce Rivalry', Arab Studies Quarterly $36 \quad$ (1), pp. 6-26. https://doi.org/10.13169/arabstudquar.36.1.0006.

Sayari, Sabri (1997) 'Turkey and the Middle East in the 1990s', Journal of Palestine Studies 26, (3), pp. 44-55.

Schweller, Randall L. (2004) 'Unanswered Threats : A Neoclassical Realist Theory of Underbalancing', International Security 29 (2), pp. 159-201.

Sinkaya, Bayram (2012) 'Rationalisation of Turkey-Iran Relations: Prospects and Limits', Insight Turkey 14 (2), pp. 137-56.

Süleymanoğlu Kürüm, Rahime (2011) 'A New Sector in Turkish Foreign Policy: Mediation', Boğaziçi Journal 25 (2), pp. 189-213.

Şener, Nedim (2010) '26 Yılın Kanlı Bilançosu' Milliyet, June 24. Avaliable at: https://www.milliyet.com.tr/gundem/26-yilin-kanli-bilancosu-1254711.

Taşpınar, Ömer (2014) 'The End of the Turkish Model', Survival 56 (2), pp. 49-64. https://doi.org/10.1080/00396338.2014.901732.

The Economist (2010) 'The Great Mediator', August 19. Available at: https://www.economist.com/europe/2010/08/19/the-great-mediator.

Tür, Özlem (2011) 'Economic Relations with the Middle East under the AKP-Trade, Business Community and Reintegration with Neighboring Zones', Turkish Studies 12 (4), pp. 589-602. https://doi.org/10.1080/14683849.2011.622515.

Tür, Özlem (2012) 'Turkey and Israel in the 2000s- From Cooperation to Conflict', Israel Studies 17 (3), pp. 45-66.

Türkmen, Füsun (2009) 'Turkish-American Relations: A Challenging Transition', Turkish Studies 10 (1), pp. 109-29. https://doi.org/10.1080/14683840802648729. 
Uzgel, İlhan (2003) 'Between Praetorianism and Democracy: The Role of the Military in Turkish Foreign Policy', The Turkish Yearbook of International Relations 34, pp. 177211.

Waxman, Dov (1999) 'Turkey and Israel: A New Balance of Power in the Middle East', The Washington Quarterly 22 (1), pp. 23-32.

Zartman, I. William and Saadia Touval (1985) 'International Mediation: Conflict Resolution and Power Politics', Journal of Social Issues 41 (2), pp. 27-45.

\begin{abstract}
About the Author
Yusuf Bera Topaloğlu is a PhD Candidate in the School of Social and Political Science, University of Edinburgh, UK. Topaloğlu's main research interests are international relations (IR) theories, foreign policy analysis, role theory, the politics of the Middle East and the Gulf politics.
\end{abstract}

